\title{
THE ANTIQUARIAN MIND: TASMANIAN HISTORY AND THE ROYAL SOCIETY OF TASMANIA 1899-1927
}

\author{
by Stefan Petrow
}

Petrow, S., 2003 (19: xii): The antiquarian mind: Tasmanian history and the Royal Society of Tasmania 1899-1927. Papers and Proceedings of the Royal Society of Tasmania, 137: 67-74. https://doi.org/10.26749/rstpp.137.67

ISSN 0080-4703. School of History and Classics, University of Tasmania, Private Bag 81, Hobart, Tasmania 7001, Australia.

Between 1899 and 1904, and again between 1921 and 1927, enthusiasts of Tasmanian history formed the Historical Section of the Royal Society of Tasmania. They sought to highlight Tasmania's rich historical traditions. They were especially interested in the deeds of foundation heroes such as explorers, governors and pioneers, but tended to ignore convict and Aboriginal history. They sought to preserve historical documents, save existing monuments and erect new monuments to their heroes, celebrate key events in Tasmania's past, and ensure places were given suitably historical names. They held lectures and published papers on their favourite aspects of Tasmanian history. They believed that history could teach valuable lessons if properly studied. This paper considers the activities of history enthusiasts in Hobart and Launceston and concludes that in small ways these enthusiasts contributed to an understanding of Tasmania's past and helped to create a public awareness of early Tasmanian achievements.

Key Words: commemoration, historical documents, historical consciousness, memorials, Royal Society of Tasmania, Tasmanian history.

\section{INTRODUCTION}

The English have long been fascinated with their past (Hey 1996). A tradition of antiquarian writing can be traced back to the Middle Ages when topographical descriptions were allied with the study of genealogy and heraldry. In the sixteenth century antiquarian studies became more firmly established and the study of manuscript material became common. The evidence of ruins, relics, coins and other non-literary sources were also consulted. In the seventeenth century the study of natural history became more popular and there was a growing interest in urban history. The antiquarian tradition flowered in the nineteenth century with the publication of numerous substantial works and the formation of record societies all over England (Levine 1986). Most of the members of these societies were untrained middle-class male elites, who were bent on recreating the English past as a source of local and national pride. As Levine has noted, Victorians revered "the home, both as a symbol of the domestic ideal and as a homeland" and this feeling "found an outlet in the national pride of the antiquarian community" (Levine 1986: 74). The antiquarian felt he had a duty to preserve information for posterity. Notable developments included the creation of the Public Record Office in 1838, the Royal Commission on Historical Manuscripts in 1869 and the British Record Society in 1888 (Hey 1996).

Drawing on an older tradition of county histories, in 1899 the monumental, multi-volumed series The Victoria History of the Counties of England was launched as a memorial to the achievements of Queen Victoria. It was conceived as "a scholarly and comprehensive encyclopaedia of English local history in all periods, a repository of essential information and the starting point for further research" (Hey 1996: 473). The general volumes comprised natural history, pre-history, the Roman and Anglo-Saxon periods, the Domesday Book, political and administrative history, ecclesiastical history and religious houses, social and economic history, forests, endowed schools and sport (Pugh 1970). The topographical volumes were divided into parishes, townships and towns. In the towns the subjects studied included manors and other estates, economic history, local government, church,
Nonconformity, education and charities for the poor. After promising much, the venture fell into abeyance from 1910 until it was revived in 1933.

The desire to preserve the past and recreate past glories was the impetus behind the formation of historical societies in late nineteenth-century Australia (Garden 1998). The first historical society was the Historical Society of Australasia formed in Melbourne in 1885 but this folded in 1886. The Australian Historical Records Society was active in Ballarat from 1896 to 1906 . State historical societies were the product of the twentieth century: in New South Wales the Australian Historical Society was formed in 1901; the Historical Society of Victoria, 1909; the Historical Society of Queensland, 1913; the Western Australian Historical Society and South Australian Historical Society, 1926.

In Tasmania no separate historical society was founded before 1930 and interest in local history was confined to a section of the Royal Society of Tasmania, the leading scientific and cultural institution. First established in 1843, the Royal Society of Tasmania is Australia's oldest scientific society. Initially formed "to develop the physical character of the Island, and illustrate its natural history and productions", in 1907 its aim was broadened to include "the prosecution of the study of science in its various branches"; in 1914 the aim was further extended to become "the advancement of knowledge" for the benefit of Tasmania (Pearson 1943: 224-226, Somerville 1943). Various sections brought together members with similar interests: the major sections included Botany, Zoology and Geology, as well as Palaeontology and Anthropology. Another, less well-known section was History and Geography. This section pioneered the study of Tasmanian history well before it made an appearance at the University of Tasmania, where Australian history was taught as a small part of British history and Tasmanian history was ignored until well after the Second World War (Macintyre 1992). From a survey of royal societies in other states, it appears that no history sections were formed, but at times lectures were given on historical topics (Maiden 1918, Madigan 1936).

The interest in Tasmanian history can be attributed to the energy of a small group of enthusiasts, who followed 
the lines of antiquarian enquiry adopted by historical societies in England and the other Australian states. These enthusiasts came from the professional classes and their interest was driven by curiosity and love of place and was not "the product of community feeling" (Fletcher 1993: ix, 55). As Griffiths (1996: 1) notes of the growth of historical consciousness in other states, this antiquarian imagination was "a historical sensibility particularly attuned to the material evidence of the past, and possessing a powerful sense of place". As Davison (1988: 67) has argued, antiquarians do not seek "to transcend the past, but to preserve it, to re-enter it, and, if necessary, to recreate it". They were especially interested in memorials and monuments, which represented the achievements of foundation heroes, notably explorers and governors (Ashton \& Hamilton 2000). The achievements of these heroes would serve as an inspiration to the younger generation (Fletcher 1993: 119).

Like history enthusiasts elsewhere, members of the Historical Section of the Royal Society wanted to record the memories and achievements of the pioneer generations for posterity (Davison 2000). Their view of history was "triumphant", to celebrate the "territory gained, settled and subdued" (Davison 2000: 200). They emphasised the first time an area had been discovered or explored as a reflection of "the genealogy of communities still striving to establish a sense of legitimacy in newly settled land". They tended to ignore, where they did not lament, the dark deeds of the past such as the killing of Aborigines or the brutality of the convict system. The convict taint still preoccupied the minds of many citizens and historians had to handle the subject with care.

We can consider the activities of the historical section in two phases. The first phase, between 1899 and 1904, was Hobart-centred and limited in achievement and the second phase, between 1921 and 1927, saw historical consciousness spread to Launceston as well and had a greater impact in various ways.

\section{PHASE 1: 1899-1904}

In May 1899 the Historical and Geographical Section of the Royal Society of Tasmania was established (RSA/H/5). It aimed to provide Fellows of the Royal Society interested in those disciplines with a chance to meet outside the monthly meetings of the society and, above all, to promote historical and geographical research into Tasmanian subjects. The driving force behind this move was the Anglican Bishop of Tasmania, Henry Hutchinson Montgomery, who became the first President of the section. The Vice-Presidents were the lawyer, James Backhouse Walker, and the photographer, John Watt Beattie. The committee members were the SurveyorGeneral, Edward Albert Counsel, the Government Statistician, Robert Mackenzie Johnston, the sanitarian, Alfred Mault, the dentist and Government Botanist, Leonard Rodway, the educationalist, Thomas Stephens, and the Anglican cleric, J.B.W. Woolnough. Professor William Jethro Brown was Treasurer and museum curator, Alexander Morton was Secretary.

The geographical element was best represented by Counsel (Elias 1981), Johnston (Wettenhall 1983), Mault (Anon. 1974), Rodway (Elias 1988) and Stephens (Smith 1976). Walker was renowned for his research into early Tasmanian history (Walker 1973). In 1884 he had toyed with the idea of forming a Tasmanian branch of the Historical Society of
Australasia, but nothing came of this (W9/C9/1). Walker thought the object of the new section should be "to gather materials for the history of Tasmania" and stop the flow of records from the island (PPRST 1898-1899: xxv). Showing an early knowledge of social history, he had a strong interest in "the growth and development of communities" and the history of the "nameless crowd" and believed history could teach valuable lessons if used correctly (The Tasmanian Mail, 26 October 1889). Beattie accumulated a museum of art and artefacts of local history, developing a special interest in convict and Aboriginal history (Roe 1979). Brown taught history as well as law at the University of Tasmania (Roe 1977) and Morton, although more interested in natural history, had begun to collect historical items for the Tasmanian Museum and Art Gallery (Huxley 2002). Woolnough's interests are unclear.

Montgomery, in the tradition of the scholar-parson with an interest in natural and local history, provided the clearest rationale for forming the section (Hey 1996). The section would concentrate on "local research; everything that bears upon the history of Tasmania will be its object", but not the history of other colonies or England, although he realised that the line could not be drawn too sharply (Tasmanian News, 20 May 1899). The section should aim "to conserve facts which will be of immense interest" in two centuries even if they may seem "trivial" now. Montgomery was inspired by the recent decision to begin "a fresh set" of county histories in England. He was also known as "the layman's Bishop" because he showed a real interest in all aspects of Tasmanian life and often asked about local history on his incessant perambulations around the state (Tasmanian News, 21 October 1901).

Montgomery suggested various ways in which the section could do "valuable work" (Tasmanian News, 20 May 1899). It should tabulate and preserve government papers languishing in government store rooms before they were destroyed or became unusable. It should acquire "old maps" from government and private sources as well as sketches, photographs and plans of Tasmanian places. Montgomery thought biography had "extreme value" in showing "the manner of life and the early difficulties". It should acquire portraits and diaries of prominent settlers and ask "all our aged friends" to record their reminiscences, especially "highly respected and venerated" members like James Agnew, Charles Butler and B.T. Solly. He thought anyone who had lived in the colony for 30 years should record his or her memories. Montgomery had already recorded his reminiscences for the benefit of his own family and he advocated study of the prospectors and pioneers of the West Coast before they died. He also referred to another neglected region of Tasmania - the King, Flinders and Barren islands, whose residents had much to tell. These islands contained the descendants of Tasmanian Aborigines, but Montgomery, although a frequent visitor, did not spell this out (Ryan 1981).

The next suggestion was to secure a collection of autograph letters of "prominent men" (Tasmanian News, 20 May 1899). Following an idea raised by The Mercury, Montgomery thought that a history of Hobart should be written. He advocated contacting all the municipalities and enlisting their help in gaining information about the reminiscences, diaries, pictures and maps in their districts. He also wanted to fill the gaps on Tasmanian history in the Royal Society library before valuable books were "carried away" to the other colonies. Finally, the Historical Section should ask 
government for "some additional spacious rooms in which to house the treasures" it would collect.

This ambitious programme was followed up by lectures. At the first meeting on 29 June 1899 Montgomery read a paper on journeys westward by W.S. Sharland in 1832 and John Franklin in 1842 (Tasmanian News, 30 June 1899). He urged members to prepare a map of the "unexplored or nearly unexplored" parts of Tasmania, which would provide an outlet for their "romantic spirits" and attract those tourists who saw themselves as "discoverers". At the next meeting, held on 1 August, Walker spoke about "The Cartography of the Terra Australia and New Holland" and Johnston gave an account of Macquarie Harbour meteorology and tides in 1825-1826 (The Mercury, 2 August 1899). In subsequent years further papers were given, such as Mault's on "Hobart Society in 1845", based on the journal of a French lady (The Mercury, 20 September 1900).

Documentary material was an early focus. In August 1899 Montgomery wrote to Premier Edward Braddon about James Bonwick's 20 volumes of transcriptions of Tasmanian official papers in the English Public Record Office (RSA/H/5). This "mass of official information" was essential to anyone writing a history of Tasmania, and Montgomery wanted the government to place it in the "safe custody" of the Royal Society. He claimed that the Royal Society in part existed "to prepare and conserve materials for the History of our colony from all points of view" and could "almost" be called "the Society for the Preservation of Historical Records". Any records it was given or acquired would not leave its premises, but would be open to bona fide researchers. However, Braddon and his colleagues believed that all "state documents" should be kept in the government archives and could not agree to Montgomery's request.

Thereafter the activities of the section slowed down. One reason for this was the death of James Backhouse Walker in November 1899. All bemoaned the loss of this "leading authority" on Tasmanian history (The Mercury, 4 and 6 November 1899). A sermon given by his friend, the Reverend George Clarke, noted that Walker took "infinite pains to verify the facts" in his quest "to get at the exact truth of things" (The Mercury, 13 November 1899). His historical work was done "for no personal gain or reward": it was a labour of love (RSA/H/5). Then in May 1900 Brown left for England (Roe 1977). The decisive blow was struck in November 1901 when Montgomery left the state. An address from the Royal Society lauded his promotion of research work on early Tasmanian history, especially the early explorers and the Aborigines (The Mercury, 7 November 1901). He left his historical paintings and books to the society.

According to up-and-coming bureaucrat and local historian John Reynolds (1966), the Historical Section continued on until 1914, but he produced no evidence to support this claim. Certainly, some Royal Society members retained their interest in history and historical papers were given, but the activities of the section seemed to have waned after Montgomery's departure (RSA/H/3). If the section had been active, then it surely would have been prominent in the celebrations of Tasmania's centenary in September 1903 and February 1904. The only member of the Historical Section to sit on the Centenary Committee was its Secretary, Alexander Morton (Tasmanian News, 19 February 1904). The September celebrations were limited to a "quiet" affair organised by the City Council in Hobart in deference to the tragic smallpox epidemic that had hit Launceston (Tasmanian News, 12 September 1903). Another possible reason was Premier W.B. Propsting's convict ancestry (Roe 2001). Although The Mercury (12 September 1903) published 20 pages on Tasmanian history (very little on the convicts), none of the articles was attributed to a member of the Historical Section. The Tasmanian News (12 September 1903) historical overview was written by Caroline Morton, Alexander's wife.

The February 1904 celebrations were more obvious and lasted longer, but were still limited to Hobart (Roe 2001). Northerners did not take an active part, but were with their "southern friends in spirit in their efforts to commemorate a noteworthy historic event" (The Examiner, 24 February 1904). This time one of the members of the Historical Section was prominent. John Beattie opened proceedings with two lectures called "Glimpses of the Lives and Times of the Early Tasmanian Governors" (Tasmanian News, 19 February 1904; The Mercury, 22 February 1904). In introducing Beattie, the Chief Justice, Sir John Dodds, said no one was better qualified than Beattie to lecture on Tasmanian history. His painstaking examination of archival records had unearthed much knowledge, "which must prove worthy of being remembered and which, but for him, would have been forgotten". Moreover, he had explored all parts of Tasmania and presented 700 photographs to the government. Apart from Beattie, the Royal Society Historical Section seems to have played no part in the celebrations, even at the unveiling of a memorial stone at Risdon, the other major historical event of February 1904 (Tasmanian News, 23 February 1904). The Tasmanian Mail (20 February 1904) produced a centenary supplement giving a solid overview of Tasmanian history, but no member of the Historical Section seems to have contributed.

The muted centenary celebrations of September and February indicated that Tasmanians were not yet fully ready to embrace their history (Roe 2001). Newspaper reflections on the past pointed in the same direction. Take The Mercury (12 September 1903) as one example. Tasmania had made satisfactory if slow progress in the past one hundred years and had overcome a "blundering" foundation by Bowen "to grow into a fair State in which peace, order, law, and general prosperity" prevailed. But the strong impression created by the newspapers was, as expressed by The Mercury, that Tasmania's dark past of "cruel suffering and many woes, amid scenes which, even now, we may shudder to recall", such as the treatment of convicts and the "destruction" of the Aborigines, should be forgotten and all should look to a brighter future. Tasmanians were better at forgetting than remembering and looked to the future not to the past. As Launceston's Daily Telegraph (12 September 1903) put it, the thought of the day was "forward rather than backward" and people cared little for precedent. Thus in its first phase the Historical Section had little impact and generated little interest either before or after the centenary celebrations.

\section{PHASE 2: 1921-1927}

\section{Hobart}

The Historical Section was revived by J. Moore-Robinson. Born in Dublin in the early 1870s, Moore-Robinson fought in the Boer War and settled in Tasmania in the early 1900s, working as a journalist on The Mercury (Biskup 1989). In 1912 
he became Secretary to the Tasmanian Tourist Association, but was dismissed in 1914 after being implicated in mismanagement of the association's finances. In 1916, with university lecturer Herbert Heaton, he revived the Historical Section as the Australian History and Economic Section, but the revival was brief (Somerville 1943). In 1916, Moore-Robinson volunteered to fight in the First World War and stayed until his discharge in February 1919; Heaton left Tasmania in 1917 (Bourke 1983). In January 1920, Moore-Robinson was appointed to the new position of librarian and publicity officer in the ChiefSecretary's Department with special responsibility for government records and newspapers stored in the vaults of the Supreme Court building in Franklin Square.

While on a tour of Melbourne and Sydney libraries, Moore-Robinson met leading historians Professor George Arnold Wood of the University of Sydney and Dr Frederick Watson, editor of the Historical Records of Australia, which aimed to make official primary records of Australian history accessible to historians (Biskup 1989). Watson visited Tasmania in late 1920 and, excited by the virgin field of Tasmanian history and Moore-Robinson's zeal, secured for the Tasmanian Government a Commonwealth grant of $£ 500$ to index and arrange Tasmanian historical records. This was an important impetus behind the revival of interest in Tasmanian history and Moore-Robinson became "Tasmania's as well as Australia's" first part-time archivist (Biskup 1989:49). He did much good work until an economy drive forced his dismissal in September 1925, whereupon he began a flax-processing company, but never lost his interest in Tasmanian history. The glaring blot on Moore-Robinson's career was the evidence, accumulated in the early 1960s, that he trafficked in Tasmanian records for personal gain (Biskup 1989).

In early 1921, Moore-Robinson became joint secretary, with University of Tasmania history lecturer Charles King, of the Geography and History Section of the Australasian Association for the Advancement of Science (Biskup 1989). At its conference he gave a paper on early Tasmanian records and stressed the importance of preserving and using the voluminous records held in the Chief Secretary's Department (The Mercury, 29 January 1921). This appears to have been the first systematic account of Tasmania's official records. To stimulate an interest in the island's history, a revised version of the lecture was given at the August meeting of the Royal Society (Moore-Robinson 1921). Moore-Robinson thought history was useful in providing "examples for present and future effort. By taking heed of its lessons, errors may be avoided, and individual and national efforts rightly directed" (The Mercury, 5 July 1924, supplement).

In July 1921, Moore-Robinson asked the Royal Society Council for authority to revive the Australian History, Geography and Ethnology section (RSA/H/3). He had a "legitimate hope" that members would produce historical work of the "illustrious" standard achieved by Walker and Beattie who, with King and others, supported the proposal. In a press release Moore-Robinson noted that Tasmanian history had been sadly neglected and suggested that early constitutional history, banking, shipping, religion and "the sad story of the decline and disappearance of the Tasmanian aborigines" all warranted "historical investigation". He hoped that the section could collect historical facts for future students, who would "collate the facts into a collected historical narrative" (RSA/H/3).

In September 1921 the section was re-established, with lawyer W.F.D. Butler as President and Moore-Robinson as
Secretary (RSA/H/1). Moore-Robinson remained Secretary until he resigned in June 1923 due to the pressure of his government work for the British Empire Exhibition (RSA/H/1; RSA/H/3). He was succeeded by John Reynolds, who praised Moore-Robinson for stimulating "a much more intelligent interest in our local history” (RSA/H/3). Reynolds continued as Secretary until December 1927 when pressure of work and a move some distance from Hobart forced him to resign (RSA/H/2). As we will see later in this paper, the section also visited the northern branch of the Royal Society and stimulated interest in early Tasmanian history and the collection of documents (PPRST 1926). The Historical Section secured the support of key members, such as Clive Lord, who was Director of the Tasmanian Museum and Secretary to the Royal Society Council (The Mercury, 17 July 1933). Lord had a deep interest in the early history of Tasmania and "in particular the records of the vanished aborigines".

We can consider the work of the Historical Section during this period in a number of areas: preserving and erecting monuments, celebrating key events in Tasmania's past, collecting historical documents, ensuring places were given suitably historical names, and giving lectures and publishing papers on Tasmanian history.

The preservation of monuments was one of the first causes. In 1922 the section became aware that some monuments in St David's cemetery, which had been handed over to the City Council as a park, were deteriorating (RSA/H/3). Governor Eardley Eardley-Wilmot's monument was in "a somewhat deplorable condition" as a principal pillar had broken away and a step was cracking. Apart from any legal obligations arising from the transfer of the cemetery, the section told the Council that the city would be disgraced "if such beautiful historic relics are allowed to suffer undue decay". The section also protested at the Council's plan "to cut out inscriptions" from headstones and set them in concrete at Queenborough Cemetery (RSA/H/1). Finally, in 1924 the Council agreed to the section's suggestion that all important tombstones be placed in the northeast corner of St David's in "a fitting and artistic manner" (RSA/H/1; MCC16/129/22: 343).

The Historical Section also attempted to save other monuments. In 1922 it asked the Scenery Preservation Board to preserve the monument to the convicts who lost their lives when the George III convict ship sank in 1835 (RSA/H/3). In 1927 when St George's burial ground was being levelled in order to build Albuera Street School the section suggested to the Director of Education, G.V. Brooks, that the monument to the politician William Race Allison should be saved and re-erected in St David's Park (RSA/H/1; RSA/H/3). Brooks obliged. A grateful Reynolds told him that since 1921 the section had "not experienced such sympathetic co-operation".

Less successful was the campaign to restore the Grecianinspired Lady Franklin Museum at Lenah Valley. In about April 1921 the local progress association first agitated for the museum to be restored to its original purpose as a botanical or forestry museum and not be used as an apple store (The Mercury, 5 September 1923, 20 July 1925). Clive Lord pleaded for public support to save the museum. He regretted "the spirit which allows the history of the past, with the attendant doings of the men and women who made Tasmania what it is to-day, to be overlooked" (The Mercury, 16 December 1925). He favoured moving the Lady Franklin Museum to St David's Park and housing in 
it Beattie's historical collection, which Tasmania was "in hourly danger of losing for all time". Tourists would be more likely to visit if the museum was in a more central location and it would be a feasible business proposition for the City Council. As the building was too brittle to move, this proposal foundered. Legal and financial entanglements blocked attempts to restore the museum in the 1920 s.

The Historical Section sought to erect monuments to prominent explorers and governors. Moore-Robinson encouraged the movement to erect a monument to Abel Tasman at his 1642 landing place (The World, 22 January, 9 October, 29 November 1923). By reading Tasman's charts and journal, Moore-Robinson led an expedition, under the auspices of the Royal Society and the State Government, to Prince of Wales Bay on the Forestier Peninsula between 12 and 15 January 1923. The expedition included "experienced official navigators, as well as men possessing intimate knowledge of the coast line, together with weather conditions experienced in the locality". When the expeditioners landed they found the stumps of four old trees in a crescent noted by Tasman in his journal. Although Tasman's charts were vague and landmarks had been obliterated, they concluded that "this indeed was the actual spot on which was made the first identifiable landing of white people, not only in Tasmania, but in Australia. It is indeed historic, if not sacrosanct". They decided that the best site for the memorial was the centre point of Tasman's crescent of trees, about 25 yards above the highwater mark. The concrete memorial was an obelisk 12 feet 6 inches high and 4 feet 6 inches at the base.

At the unveiling ceremony on 3 December 1923, the Administrator Sir Herbert Nicholls, who had first suggested a memorial, said "preservation of historical knowledge is of vast importance" (The World, 4 December 1923). The Royal Society deserved praise for "keeping Tasmania's reputation as a place where ...thought, art, poetry and history are regarded as greater than wealth". Nicholls called Tasman "the godfather of this beautiful island". Two weeks later the euphoria was deflated at a meeting of the Royal Society when some members questioned whether the memorial had been placed in the correct position (The Mercury, 18 December 1923). Moore-Robinson was incredulous that despite all the publicity and discussion about the memorial it should be disputed after the unveiling and not before. He explained how they arrived at the spot which, he felt convinced, was "as near as possible to the place where Tasman's carpenter landed and planted the flag of his country". Pointing out the difficulties of finding the exact spot, Clive Lord, who contrary to Moore-Robinson had stated his reservations about the site in October 1923 (Reynolds 1966), revisited divergent investigations of Tasman's landing place by the Reverend J.P. Gell and James Backhouse Walker, both of whom differed from the expedition's spot. Lord noted that Tasman recorded that he could see the Dutch flag from his ships but it would have been "impossible to see if planted on the present site of the memorial". Lord believed that the four trees noted by Tasman were 200 yards to the north of the memorial. Arguments sallied to and fro, and uncertainty grew. Finally, the meeting resolved that the inscription on the memorial should be changed from "at this spot" to "near this spot".

This decision did not end the dispute. In December 1925, G.H. Halligan, former hydrographer and supervising engineer to the New South Wales government, stunned a Royal Society meeting by claiming that his investigations indicated that Tasman had landed some two miles southeast from where the memorial had been placed (The Mercury, 15 December 1925). Lord thought Halligan was wrong and restated his view that the memorial had been wrongly located. Lord (1926) followed up his assertions on the planting of the Dutch flag in a paper published in the Papers and Proceedings of the Royal Society.

Moves to erect other memorials were less contentious. For example, in 1927 the section decided to place a suitable tablet to commemorate Governor David Collins' landing at Sullivan's Cove (RSA/H/1). The most suitable spot was the wall of an ice factory owned by Jones and Company. With the practical and financial support of the company and Lady Jones, the wife of the company's founder, the project was completed. The tablet, which cost $£ 60$, read "David Collins landed near this spot Hunter's Island and Founded the City of Hobart on 20 February 1804" (RSA/H/1; PPRST 1927: 232).

The $1920 \mathrm{~s}$ was a time to celebrate important centenaries. These included the centenary in 1924 of the Supreme Court (The Mercury, 9 April 1924) and of the oldest law firm, Butler, McIntyre and Butler (The Mercury, 2 July and 23 September 1924); and in 1925 of the Legislative Council (The Mercury, 17 July 1925), of the first school (The Mercury, 10 December 1925) and of the Richmond Court House (The Mercury, 17 and 21 December 1925). The Historical Section seems not to have played a part in these celebrations. It did, however, organise a centenary dinner to commemorate Van Diemen's Land's separation from New South Wales in December 1825 (known popularly as Independence Day) because, noted The Mercury (3 December 1925) "an extraordinary apathy, or myopia" had "smitten" the Lyons government about this celebration. One possible reason for official apathy was the death of Queen Alexandra (The Mercury, 4 December 1925). At the dinner the president of the Historical Section, W.F.D. Butler, outlined the history of Van Diemen's Land to the declaration of independence (The Mercury, 4 December 1925). Other members registered more sombre thoughts. The Chairman of the Royal Society Council, Leonard Rodway, referred to "the extermination of the original owners of the island", the Tasmanian Aborigines, who were "a fine race before the arrival of the white man". He regretted from "a scientific point of view" that the Tasmanian Museum had not collected more Aboriginal exhibits. Dr William Crowther, a compulsive collector and dedicated medical historian, angrily denounced the wilful destruction or removal from the State of so many historical documents and urged that existing records on the Aborigines be "carefully collaborated and preserved".

Although the Historical Section spoke sympathetically about the Aborigines and celebrated some aspects of Tasmania's past, it did have one obvious blind spot. Tasmania's convict past received little attention. This reflected wider community views. For example, in 1921 Tasmanian-born Thomas Dawson told The Mercury (29 September 1921) readers that convict buildings should be "turned into churches and packing sheds". Tasmanians could not "feel any pride" in the convict system, which "so ill-used" men that they "almost became brutes". Dawson wanted the name of Port Arthur wiped "off the map". Not everyone agreed (see The Mercury, 8 October 1921 , letter by "Meataxe" and 22 October 1921, letter by H. Benjafield), but the Historical Section showed a lack of interest or sensitivity to the convict past. In December 1925, William Crowther advocated placing parts of Beattie's 
historical collection relating to governors in the Tasmanian Museum, but thought that the Port Arthur relics "might be discarded in their entirety or otherwise disposed of" because they were "a small and the least interesting part of the collection" (The Mercury, 23 December 1925).

To be sure some members of the Historical Section did study convict themes. For example, Moore-Robinson wrote about Port Arthur and Lord (a descendant of a convict) wrote about Port Puer, both indicating a growing acceptance of the convict past, but there were limits (Young 1996). The Historical Section's anti-convict bias was most strongly manifested in its reaction to the filming in Tasmania of Marcus Clarke's novel For the Term of His Natural Life (Roe 1989). On 9 August 1926, A.N. Lewis moved that the Royal Society thought Clarke's novel did not represent "true history" (The Mercury, 10 August 1926). As "the tradition of American cinema producers is contrary to the representation of true history", and as they had shown "only an ability to pervert facts for money-making purposes, this society condemns" the film. It considered the film "to be against the best interests of Tasmania and historical studies", and directed the Council to oppose and discourage the production. Lewis argued that the novel did not portray "what actually happened" at Port Arthur, which in any case played "a very unimportant part" in Tasmanian history. The film would not be "real history" but "a "love" story with a background of man-traps, chain gangs, and other horrors". Lord seconded and Crowther supported the motion. Crowther did not think that the "brutal and degrading" convict past should be allowed "to go on in perpetuity". The Bishop of Tasmania, Dr Robert Snowdon Hay, preferred to see all associations "with the days of penal settlement" in Tasmania "scrapped forever". Chairman Rodway represented those members who thought too much fuss was being made and that the film should have been ignored, but the motion passed by "a small majority". The film went on to become a popular success in Hobart, perhaps revealing an unexpected interest in the darker side of Tasmanian history (Roe 1989).

One key aim of the Historical Section was to uncover the existence of historical documents on Tasmania, take custody of them and make them available to students of Tasmanian history $(\mathrm{RSA} / \mathrm{H} / 3)$. To stimulate interest in "the discovery of historical documents", Moore-Robinson persuaded Dr Frederick Watson, editor of the series Historical Records of Australia, to talk on "The Writing of Australian History" (The Mercury, 11 October 1921). After Watson's lecture John Beattie described the destruction of past records as "dreadful" and denounced Tasmanian legislators for allowing the records to be "pillaged and destroyed". It is unclear how successful the Historical Section was in securing custody of historical records. We have definite evidence of W.F. Rawnsley donating some Franklin manuscripts, including Lady Franklin's diaries, in 1924 (PPRST 1924) and of the Society acquiring a copy of the Reverend Robert Knopwood's diary in 1926 (PPRST 1926). We will never really know how many records Moore-Robinson might have collected but sold on to collectors.

Another aim of the Historical Section was to ensure that "suitable names" were applied to new areas and to preserve the accuracy of places "intimately associated" with the early settlement of Tasmania (RSA/H/3). In February 1922 the section pointed out to H.W. Gepp, manager of the Electrolytic Zinc Company, that the name Risdon, which had been used for his company's works, had been used by
Bowen for the first settlement on the eastern side of the Derwent in 1803 (RSA/H/3). The section thought that, "from an historical point of view", the name Risdon should remain "definitely associated with this historical locality". While sympathising with efforts to prevent "the mutilation or destruction of the historical significance of Tasmanian names", Gepp would not change because his company and its products had been for some years associated with the name Risdon and any change would confuse his customers and involve "monetary loss". In 1925, Moore-Robinson also protested at the Council's inclination to rename St David's Park as Wilmot Park and made the case for keeping the name St David's (The Mercury, 4 May 1925). This time history triumphed and St David's was retained (The Mercury, 12 May 1925).

The final area we should consider is the holding of lectures and publishing of papers. While not a definitive list, we can identify lectures in 1921 on an 1839 voyage to England by William Crowther's grandfather (RSA/H/1); in 1922 on Macquarie's visits, Grime's survey of King Island, Knopwood's journal, early Hobart regattas, the currency used before 1825 and aspects of George Arthur's governorship (RSA/H/1); in 1923 on early industry and the Lady Franklin Museum (RSA/H/1); in 1925 on John Franklin's governorship (The Mercury, 25 December 1925); in 1926 on William Denison's governorship (RSA/H/1); and in 1927 on David Collins' governorship (PPRST 1927). Some of these lectures formed the basis of papers that were published in the Papers and Proceedings of the Royal Society (Somerville 1943; PPRST 1922-27 passim).

In 1927 the Historical Section became embroiled in a controversy when an article in The Tasmanian Mailcriticised lectures on Collins' period as Governor (The Tasmanian Mail, 10 August 1927). According to the Mail, in the past "some of the scientific papers" read at Hobart meetings had "gained prominence in the highest quarters of the scientific world", but fewer people had an interest in science now and the Royal Society was in decline as a result. Symptomatic of decline were the lectures on Collins, which were given by "junior" members. Although some papers were "interesting in a way", they revealed nothing "new" and some were "not above the standard of essays done in the $5^{\text {th }}$ and $6^{\text {th }}$ forms of secondary schools".

The article was hurtful but hardly devastating, yet the section took the attack to heart because it implied that the society was "decadent", which in this context meant decaying or dying (RSA/H/2). As Reynolds explained to the Secretary of the Royal Society, the article would prevent some members from speaking in the future and weaken interest in Tasmanian history. The lecturettes were not papers prepared for publication as the society's scientific papers were, but "short talks giving sidelights" of Tasmanian history. Clive Lord was also incensed. He pointed out that in ten years the Society's membership had increased from 88 to 250 and in the same period the scientific papers were the equal of any published in the past $(\mathrm{RSA} / \mathrm{H} / 2)$. He disparaged the tendency to belittle "all that is Tasmanian". The Royal Society Council declined to respond to the article. After the criticisms, the Historical Section in Hobart seems to have fallen into abeyance. Individual members continued to give papers on historical subjects, but not as members of the section.

Despite its unprecedented efforts, some members thought the discussion of Tasmanian history should not be confined to the Historical Section of the Royal Society. The section's 
scope was "limited" because its members were very busy men (PPRST 1925: 246). In July 1926 William Crowther suggested forming a Tasmanian historical society, but other members thought that "the time was not ripe for the inauguration of such a movement" (RSA/H/1, 8 July 1926). This in part reflected an elitist view and in part a belief that Tasmanians were still not ready to confront their past.

\section{Launceston}

In April 1921, Moore-Robinson visited Launceston looking for old records and found a "magnificent field" for historical research (The Examiner 28 April 1921). As evidence of a strong historical tradition in the north, he referred to some of Launceston's past eminent historians - John West, Ronald Gunn, Charles W. Rocher and Ernest Whitfeld - and suggested either that interested persons form an historical society as existed in Melbourne and other centres or that an historical section form part of a northern branch of the Royal Society, which had existed in the early 1860s. On 18 May a meeting decided to reform a northern branch of the Royal Society, but history did not loom very large in the branch's activities (The Examiner, 19 May 1921; RSNB Minute Book).

In 1926 Moore-Robinson was again the catalyst for public discussion on historical research. In June he spoke to the northern branch of the Royal Society on Governor Lachlan Macquarie's visits to Van Diemen's Land in 1811 and 1821, with special reference to Launceston (The Examiner, 22 June 1926). He urged members "to do sorne little thing to place on record some essential fact of which he or she has knowledge". As areas of research he suggested ships and shipping on the Tamar, banks and the names of places. In supporting Moore-Robinson, lawyer J.E. Heritage thought schoolchildren "should be educated to a better appreciation of Tasmanian history", whereby they would "learn something they had not got at present - that was love of their country". A small committee was set up to consider ways of finding out what old records existed in Launceston. At a later meeting to consider forming an association for historical research, Moore-Robinson raised the idea of forming a Tasmanian Historical Society because members of the Royal Society outside Hobart felt aggrieved that their "local subscriptions were not available for local requirements" and that, "generally speaking, interest centred in the society's premises in Hobart" (The Examiner, 9 July 1926). Moreover, the Royal Society was mainly a scientific body, but many people were more interested in historical research and wanted to meet like-minded others. The meeting decided to talk with members of the Royal Society before taking any action.

At that meeting on 23 July all agreed that two competing societies could not survive in Launceston and that it would be better if the Royal Society more actively encouraged historical interests and assisted in the collection of old records (The Examiner, 24 July 1926; RSNB Minute Book). A journal to disseminate historical articles was considered but rejected. Thereafter lectures on historical topics featured more regularly at meetings of the northern branch. These included, in 1927, educationist, historian and anthropologist A.L. Meston on "The Growth of a Constitution in Tasmania" and an informal meeting on recollections of early Launceston, where "personal reminiscences" of people, buildings and social conditions of the early 1860 s were related (The Examiner, 23 June 1927 and 13 June 1928). An interest in history was further stimulated when, much to the chagrin of Hobart enthusiasts, the Queen Victoria Museum acquired, in late 1927, John Watt Beattie's collection on the early history of Tasmania (The Examiner, 13 June 1928; Young 1996).

\section{CONCLUSION}

It has been fashionable in some circles to claim that Tasmanians have lacked interest in their history. For example, in the 1980s Kay Daniels (1983: 3) thought that Tasmania was a "society which is still uncomfortable with its past, which sees its history as in some ways marked by a shameful inheritance" and Peter Conrad (1988: 96) once suggested that Tasmania had "unwritten its own history" to conform with "a self-protective incuriosity about origins". These comments are true to a point if we see Tasmanian history through the eyes of the Aborigines and the convict system and if we ignore other aspects of our history.

This paper has shown that the members of the Historical Section of the Royal Society were curious about Tasmanian history long before the 1980s. Some members studied the dark side, but only to whitewash the past by stressing the benefits of the convict system. Most members embraced other, more positive aspects of the past. They emphasised the bravery and intelligence of the early explorers, the development of constitutional forms and how successive governors overcame difficulties to create a viable society from unpromising beginnings. Mostly, they took an uncritical approach to their subjects and were celebratory, nostalgic and preservationist. As befitting men of their class, position and respectability in society, they were interested in celebrating but not challenging the status quo. They showed no interest in giving voices to the subaltern classes and the achievements of women hardly rated a mention unless they were married to a governor. Tasmanian history was a story of progress and the triumph of man's will and there was no need to acknowledge, let alone apologise, for the sins of the past.

Mostly, as determined by the lecture format, the research of section members was superficial. No member of the section attempted a penetrating monograph to explore diverse themes of Tasmanian history. They lacked either the training or the inclination, or both, to emulate the impressive general histories written by Henry Melville (1835), John West (1852) or James Fenton (1884). They were more comfortable in focusing on the facts and small, self-contained topics, which were accessible to their small number of conservative colleagues. But too much could not be expected of these pioneers of our local history. In small, tentative ways members of the historical section contributed to an understanding of Tasmania's past, helped to create a public awareness of early Tasmanian achievements, and did something to further the Royal Society's aim to advance knowledge. The approach might have been antiquarian, but in reminding Tasmanians that they had a history worth remembering and by collecting historical documents their work had value nonetheless. 


\section{REFERENCES}

Ashton, P. \& Hamilton, P., 2000: Blood money? Race and nation in Australian public history. Radical History Review 76: 188-207.

Anon., 1974: Alfred Mault (1829-1902). Australian Dictionary of Biography. Melbourne University Press, Melbourne 5: 229-30.

Biskup, P., 1989: J. Moore-Robinson, a trader in records, in Papers and Proceedings of the 7th biennial conference of the Australian Society of Archivists, Inc, Hobart 2-6 June 1989: 46-56.

Bourke, H., 1983: Herbert Heaton (1890-1973), Australian Dictionary of Biography, Melbourne University Press, Melbourne 9: 250-251.

Conrad, P., 1988: Down Home: Revisiting Tasmania. Chatto \& Windus, London.

Daily Telegraph newspaper (Launceston), references as cited in the text.

DANiELS, K., 1983: Cults of nature, cults of history. Island Magazine 16: 3-6.

DAvison, G., 1988: The use and abuse of Australian history. Australian Historical Studies 23: 55-76.

Davison, G., 2000: The use and abuse of Australian history. Allen $\&$ Unwin, St Leonards.

EuIAS, A., 1981: Edward Albert Counsel (1849-1939). Australian Dictionary of Biography, Melbourne University Press, Melbourne 8: 121-122.

Elias, A., 1988: Leonard Rodway (1853-1936). Australian Dictionary of Biography. Melbourne University Press, Melbourne 11: 436-437.

The Examiner newspaper (Launceston), references as cited in the text.

Fenton, J., 1884: A history of Tasmania from its discovery in 1642 to the present time. Walch \& Sons, Hobart.

Fletcher, B.H., 1993: Australian history in New South Wales 1888-1938. University of New South Wales Press, Kensington.

GARDEn, D., 1998: Historical societies. In Davison, G., Hirst, J., \& Macintyre, S. (Eds): The Oxford companion to Australian history, Oxford University Press, Melbourne: 318-319.

GRIFFITHS, T., 1996: Hunters and collectors: The antiquarian imagination in Australia. Cambridge University Press, Cambridge.

Halligan, G.H., 1925: Tasman's landing place. Papers and Proceedings of the Royal Society of Tasmania: 195-202.

HeY, D. (ed), 1996: The Oxford companion to local and family history. Oxford University Press, Oxford.

HuxLEy, J., 2002: Curatorial zeal: the contribution of Alexander Morton to the Tasmanian Museum and Art Gallery 1884-1907. Unpublished B.A. (Hons) thesis, University of Tasmania.

LEVINE, P., 1986: The amateur and the professional: antiquarians, historians and archaeologists in Victorian England, 1838-1886. Cambridge University Press, Cambridge.

LORD, C., 1926: On the planting of the Dutch flag in Tasmania in 1642. Papers and Proceedings of the Royal Society of Tasmania 1926: 25-34.

MACINTYRE, S., 1992: History, a school for statecraft; or How shall we sing the Lord's song in a strange land? Tasmanian Historical Research Association Papers and Proceedings 39 (3): 105-117.

MAdigAn, C. T., 1936: Centenary Address: The past, present and future of the Society and its relation to the welfare and progress of the State. Transactions of the Royal Society of South Australia 60: i-xv.

MAIDEN, J.H., 1918: A contribution to a history of the Royal Society of New South Wales (with information in regard to other New South Wales societies). Journal and Proceedings of the Royal Society of New South Wales 52: 215-361.

MCC16/129/22, Minutes of the meetings of the Hobart City Council, Archives Office of Tasmania.

Melville, H. S., 1835: History of the island of Van Diemen's Land, from the year 1824 to 1835: inclusive, to which is added a few words on prison discipline. Smith \& Elder, London.
The Mercury newspaper, references as cited in the text.

Moore-Robinson, J., 1921: Tasmanian State records. Papers and Proceedings of the Royal Society of Tasmania 1921: 156-65.

Pearson, J., 1943: Centenary of the Royal Society of Tasmania. Papers and Proceedings of the Royal Society of Tasmania 1943: 223-231.

PPRST, 1898-1899: Minutes of annual meeting, 27 March 1899. Papers and Proceedings of the Royal Society of Tasmania 1898-1899: xxiii-vi.

PPRST, 1924: Annual report for 1924. Papers and Proceedings of the Royal Society of Tasmania 1924: 154-156.

PPRST, 1925: Historical and Geographical section report 1925. Papers and Proceedings of the Royal Society of Tasmania 1925: 244-246.

PPRST, 1926: Annual report for 1926. Papers and Proceedings of the Royal Society of Tasmania 1926: 184-186.

PPRST, 1927: Annual report of the Historical Section 1927. Papers and Proceedings of the Royal Society of Tasmania 1927: 232

Pugh, R.B., 1970: The Victoria history of the counties of England. Oxford University Press, London.

ReYNOLDS, J., 1966: Some recollections of the Tasman memorial controversy. Tasmanian Historical Research Association Papers and Proceedings 13 (2): 39-49.

Roe, M., 1977: William Jethro Brown: an Australian Progressive, 1868-1930. University of Tasmania, Hobart.

Roe, M., 1979: John Watt Beattie (1859-1930). Australian Dictionary of Biography. Melbourne University Press, Melbourne 7: 232-233.

RoE, M., 1989: Vandiemenism debated: the filming of "His natural Life" 1926/7. Journal of Australian Studies 24: 35-51.

RoE, M., 2001: The state of Tasmania: identity at Federation time. Tasmanian Historical Research Association, Hobart.

RSA/H/1: Minute book of the Historical and Geographical Section 19 May 1899-20 September 1900, 2 September 1921-20 July 1927, Royal Society of Tasmania papers, University of Tasmania Archives.

RSA/H/2: Papers of the Historical and Geographical Section 1899-1927, Royal Society of Tasmania papers, University of Tasmania Archives.

RSA/H/3: Letterbook of the Historical and Geographical Section 1899-1927, Royal Society of Tasmania papers, University of Tasmania Archives.

RSA/H/5: Scrapbook of the Historical and Geographical Section 1899-1904, Royal Society of Tasmania papers, University of Tasmania Archives.

RSNB Minute Book, Royal Society of Tasmania Northern Branch, State Library of Tasmania Launceston.

RYAN, L., 1981: The Aboriginal Tasmanians. University of Queensland Press, St Lucia.

Smith, N., 1976: Thomas Stephens (1830-1913). Australian Dictionary of Biography. Melbourne University Press, Melbourne 6: 196 .

Somerville, J., 1943 The Royal Society of Tasmania 1843-1943. Papers and Proceedings of the Royal Society of Tasmania 1943: 199-221

The Tasmanian Mail newspaper, references as cited in the text.

Tasmanian News newspaper, references as cited in the text.

W9/C9/1: Notes and correspondence on the proposed Historical Society 1884, James Backhouse Walker papers, University of Tasmania Archives.

WalKer, J.B., 1973: Early Tasmania: papers read before the Royal Society of Tasmania during the years 1888 to 1899. Government Printer, Hobart.

WeST, J., 1852: The history of Tasmania, 2 vols. Henry Dowling, Launceston.

WetTENHALL, R.L., 1983: Robert Mackenzie Johnston(e) (18431918). Australian Dictionary of Biography. Melbourne University Press, Melbourne 9: 501-503.

The World newspaper, references as cited in the text

YounG, D., 1996: Making crime pay: the evolution of convict tourism in Tasmania. Tasmanian Historical Research Association, Hobart.

(accepted 29 September 2003) 